\title{
Examination of Wood Adhesive Bonds via MicroCT: The Influence of Pre-Gluing Surface Machining Treatments for Southern Pine, Spotted Gum, and Darwin Stringybark Timbers
}

\author{
William Leggate, ${ }^{\mathrm{a}, \mathrm{b}, *}$ Maryam Shirmohammadi, ${ }^{\mathrm{b}}$ Robert L. McGavin, ${ }^{\mathrm{b}, \mathrm{c}}$ \\ Andrew Outhwaite, ${ }^{\mathrm{b}}$ Mark Knackstedt, ${ }^{\mathrm{a}}$ and Matthew Brookhouse ${ }^{\mathrm{d}}$
}

\begin{abstract}
The successful manufacturing of glulam from several important Australian commercial timbers is quite challenging due to difficulties in gluing. Improvements in adhesive bond performance of spotted gum, Darwin stringybark, and southern pine timber have been achieved using alternative pre-gluing surface machining methods, e.g., face milling and sanding-post planing, when compared to conventional planing methods. In order to improve the understanding of the effects that different surface machining methods have on adhesive bond performance, this study used micro X-ray computed tomography and microscopy to assess key adhesive bond criteria. There was a considerable loss in the amount of adhesive after the wet and dry test cycles for all species. There was also an extremely high frequency of voids in the glue lines for all species, which would negatively impact bond strength and durability. Face mill prepared timber boards resulted in thicker glue lines and greater resistance to adhesion loss, compared to boards prepared via planing. For the two hardwood species, face milling also resulted in greater adhesive penetration; however, for southern pine, there were no significant differences in adhesive penetration between the three surface machining treatments. Adhesive penetration was much deeper in southern pine compared to spotted gum and Darwin stringybark.
\end{abstract}

Keywords: Wood surface machining; Wood adhesion; Adhesive penetration; Glue line; Pinus elliottii; Pinus caribaea; Corymbia citriodora; Eucalyptus tetrodonta; Micro x-ray computed tomography

Contact information: a: Research School of Physics and Engineering, The Australian National University, Canberra, ACT 0200 Australia; b: Queensland Department of Agriculture and Fisheries, Horticulture and Forestry Science, Salisbury Research Facility, 50 Evans Rd, Salisbury, QLD 4107 Australia; c: School of Civil Engineering, The University of Queensland, St. Lucia, Queensland 4072 Australia; d: Fenner School of Environment and Society, Canberra, ACT 0200 Australia;

*Corresponding author: william.leggate@daf.qld.gov.au

\section{INTRODUCTION}

Three commercially important timbers produced in Queensland, Australia are southern pine (Pinus elliottii, Pinus caribaea, and a hybrid between these two species), spotted gum (Corymbia citriodora), and Darwin stringybark (Eucalyptus tetrodonta). There is a rapidly growing industrial interest in increased usage of these timbers for sawnlaminate based structural engineered wood products (EWPs), e.g., glued laminated timber (glulam). However, a major impediment to increased and more profitable use of these species for this purpose is the difficulty in cost-effectively gluing these timbers. This is due 
to their relatively high wood density and their particular wood chemistry when compared to many other commercial timber species (Leggate et al. 2020, 2021a,b).

One key research strategy being implemented to explore a commercially viable solution to achieve better bond performance for these timbers involves the investigation of alternative methods for preparing the wood surface before gluing (Leggate et al. 2020, 2021a,b). Surface machining prior to gluing is a standard method adopted to improve wood adhesion. Currently, the planing of the wood surface immediately before gluing is the most common method used internationally (Knorz et al. 2015). However, recent studies by Leggate et al. (2020, 2021a,b) have shown that alternative methods, e.g., face milling and sanding post-planing, can improve the wettability and gluability of southern pine, spotted gum, and Darwin stringybark timber compared to planing. Studies with other species have also shown similar findings (Kläusler et al. 2014; Knorz et al. 2015; Vella 2020). Wood face milling is not currently used in Australia as a commercial approach to wood preparation before gluing and has only recently been investigated as an alternative surface machining option for Australian timbers (Leggate et al. 2020, 2021a,b).

This study forms part of a series of experiments investigating the effects of different wood surface machining methods on wood adhesion for major Australian commercial timbers. Previous studies reported by Leggate et al. (2020, 2021a,b) detailed the impact of different mechanical surface machining techniques on the wettability, permeability, and gluability (through lap shear testing) of southern pine, spotted gum, and Darwin stringybark. The key conclusions from these studies were that conventional planing produced the lowest surface wettability compared to the other surface machining methods. Improved wettability was achieved using face milling and sanding treatments post-planing. For spotted gum and Darwin stringybark, planing also produced the lowest permeability, whereas face milling resulted in the highest permeability. Particular face milling configurations and sanding treatments post-planing also significantly improved the tensile shear strength of the glued wood joints compared to planing. It was hypothesized during these studies that the performance differences were likely attributable to differences in the resulting board surface roughness, fibrillation, and sub-surface cellular damage that resulted from the different machining. This resulting influence affected the adhesive penetration, glue line thickness, etc., and ultimately the bond integrity and performance.

In order to test these hypotheses and further improve the understanding of the effect that different surface machining approaches have on adhesive bond performance, this study assessed key criteria, e.g., adhesive penetration, glue line thickness, and voids in glue lines. The penetration of an adhesive into the porous wood structure is believed to have a strong influence on bond strength, durability, and performance (Collett 1972; Frihart 2004; Marra 1992; Sernek et al. 1999; Paris 2014; Luedtke et al. 2015). However, there is limited direct experimental evidence demonstrating the link between adhesive penetration depth and bond performance in glued wood joints, as the optimum depth of penetration is not known (Sernek et al. 1999; Paris 2014; Bastani et al. 2016). Adhesive penetration also has an economic impact as on a unit weight basis; adhesive is much more expensive than wood, and more adhesive is required to compensate for the penetration (Bastani et al. 2016). Adhesive penetration into wood can occur in various forms, including gross penetration and penetration into cell walls. Gross penetration is the movement of the adhesive into the cell lumens as well as into inter-cellular voids, whereas cell wall penetration is the diffusion or infiltration of the adhesive into the cell walls (Kamke and Lee 2007; Frihart 2012; Dugmore 2018; Jakes et al. 2018). However, not all adhesives can penetrate cell walls, with current data suggesting that cell wall penetration is achieved only by in-situ 
polymerized adhesives with low molecular weight fractions, e.g., phenol formaldehyde (PF) and resorcinol formaldehyde (RF) (Frihart 2012). There is no experimental evidence to demonstrate that pre-polymerized adhesives, e.g., polyurethanes (PUR), can penetrate cell walls (Frihart 2012; Dugmore 2018; Jakes et al. 2018; Pröller et al. 2018).

The glue line is the zone of bulk adhesive between the wood surfaces, which not only bonds the timber boards (or lamellas) together, but also absorbs and compensates for the arising tensions of the lamellas (Marra 1992; Wetzig et al. 2011; Luedtke et al. 2015). Therefore, the glue line thickness is an important factor influencing the bonding performance of wooden joints (Kurt and Cil 2012; Bomba et al. 2018). It influences the mechanical properties of the joint and has a clear economic impact on the production process (Arenas et al. 2010; Kurt and Cil 2012). Recommended glue line thicknesses vary depending on the type of stress being imposed on the joint, the properties of the adherent, and the type of adhesive (da Silva et al. 2006). There is a threshold for recommended glue line thickness for different applications, where values below and above can reduce bond performance. When the glue line thickness is within the optimum range, the adhesive performance is maximized, since the load transfer is maximized and the creep is minimized (Kellar 2005). Excessive adhesive penetration can lead to a glue line that is too thin (starved glue line), which results in increased probability of delamination (Wetzig 2009; Dugmore 2018). Voids in the cured adhesive in bond lines can reduce the bond strength and durability and minimizing or eliminating air bubbles is essential to achieving the strongest bond (Sage and Tiu 1982; Duhamel 2016; Permabond 2021a).

Diverse technologies and methods have been adopted to examine glue lines and adhesive penetration in wood. These methods include light microscopy (LM), scanning electron microscopy (SEM), backscatter electron imaging, wavelength dispersive spectroscopy, fluorescence microscopy (FM), X-ray fluorescence microscopy, transmission electron microscopy (TEM), UV-microscopy, electron energy loss microscopy, chemical state X-ray microscopy, confocal laser scanning microscopy (CLSM), scanning thermal microscopy, nanoindentation, small-angle neutron scattering, and micro X-ray computed tomography (MicroCT) (Modzel et al. 2011; Qin et al. 2017; Jakes et al. 2018). All of these technologies and approaches have advantages and disadvantages in terms of the nature and level of information generated, scale, ease of use, sample preparation requirements, resolution, cost, data set size, and complexity. However, various researchers have demonstrated the particular usefulness of MicroCT in studying wood adhesive bonds in 3D (Evans et al. 2010; Modzel et al. 2011; Hass et al. 2012; Kamke et al. 2014; Paris 2014; Paris and Kamke 2015; Bastani et al. 2016; McKinley et al. 2016; Qin et al. 2017; Jakes et al. 2018).

This study extends the previous work reported by Leggate et al. $(2020,2021 \mathrm{a}, \mathrm{b})$ by using imaging techniques including MicroCT and light microscopy to examine the relationships between wood surface machining methods, gluability, glue line, and wood anatomical features for southern pine, spotted gum, and Darwin stringybark.

\section{EXPERIMENTAL}

\section{Wood Material}

The wood samples used for this study were prepared using similar methods to those described by Leggate et al. (2020, 2021a,b) and adopted during parallel studies investigating the effects of different surface machining methods on the wettability, 
permeability, and gluability of southern pine, spotted gum, and Darwin stringybark timber. These species represent important commercial softwood and hardwood timber species processed by the Queensland, Australia forest products industry. The difficulties in gluing southern pine increase with higher density wood. Therefore, targeting machine graded pine grade MGP15 (in accordance with AS/NZS standard 1748.1 (2011) and AS standard 1720.2 (2006)) in this study ensured that higher density southern pine was biased in the board selection. The spotted gum and Darwin stringybark boards were defect free feedstock destined for milled products, e.g., flooring and decking. Seasoned (dried) boards were randomly selected from packs obtained from commercial processors of these timbers.

\section{Sample Preparation}

For each species, and as part of the parallel studies referred to above (Leggate et al. 2020, 2021a,b), the boards were initially machined into pieces with dimensions of $20 \mathrm{~mm}$ $\times 11 \mathrm{~mm} \times 450 \mathrm{~mm}(\mathrm{~W} \times \mathrm{T} \times \mathrm{L})$. These pieces were then conditioned in a constant environment chamber set at a temperature of $20{ }^{\circ} \mathrm{C}$ and a relative humidity $(\mathrm{RH})$ of $65 \%$ ( $12 \%$ equilibrium moisture content [EMC]). After conditioning, the pieces were randomly allocated to three different mechanical surface machining preparations (as shown in Table $1)$.

Table 1. Mechanical Surface Machining Preparations

\begin{tabular}{|c|c|c|c|}
\hline $\begin{array}{c}\text { Surface } \\
\text { Machining } \\
\text { Identifier }\end{array}$ & $\begin{array}{c}\text { Surface Machining } \\
\text { Method }\end{array}$ & Cutter Specifications & $\begin{array}{c}\text { Feed, Cutter and Sanding } \\
\text { Speeds }\end{array}$ \\
\hline SM1 & Face milling & $\begin{array}{c}\text { Type: Tungsten Carbide } \\
\text { Pt No: Leucodur }-\mathrm{HL} 40 \\
\text { Dim: } 14 \times 14 \times 2 \mathrm{~mm} \\
48 \text { Cutters @ } 520 \mathrm{~mm} \text { diameter }\end{array}$ & $\begin{array}{c}\text { Feed rate }=45 \mathrm{~m} / \mathrm{min}, \\
\text { Cutter speed }=2100 \mathrm{rpm}(57 \\
\mathrm{m} / \mathrm{s})\end{array}$ \\
\hline SM2 & Planing & $\begin{array}{c}\text { High Speed Steel Blade } \\
40.5^{\circ} \text { Blade tip angle } \\
120 \text { mm Cutterblock diameter }\end{array}$ & $\begin{array}{c}\text { Feed Rate: } 8 \mathrm{~m} / \mathrm{min} \\
\text { Cutter speed: } 4500 \mathrm{rpm}(28 \\
\mathrm{m} / \mathrm{s})\end{array}$ \\
\hline SM3 & $\begin{array}{c}\text { Sanding } \\
\text { (40 grit) post- } \\
\text { planing }\end{array}$ & $\begin{array}{c}\text { Belt : KLINGSPOR PS 29 F } \\
\text { Grit: Aluminum Oxide } \\
\text { Backing: Paper }\end{array}$ & $\begin{array}{c}\text { Planed } 8 \mathrm{~m} / \mathrm{min} \mathrm{feed} \mathrm{rate}+ \\
\text { Sanding using } 40 \mathrm{grit} \text { belt } \\
\text { removing } 0.3 \mathrm{~mm} \\
\text { Belt Speed }=18 \mathrm{~m} / \mathrm{min} \\
\text { Feed rate }=3.5 \mathrm{~m} / \mathrm{min}\end{array}$ \\
\hline
\end{tabular}

The machining treatments, i.e., face milling, sanding, and planing (as described in Table 1), were conducted as explained in previous work by Leggate et al. (2020, 2021a,b). During each surface machining process described in Table 1, $1.5 \mathrm{~mm}$ was removed from the upper and lower timber surface to reduce the thickness from $11 \mathrm{~mm}$ to $8 \mathrm{~mm}$. The pieces were then docked to produce $20 \mathrm{~mm}$ × $8 \mathrm{~mm}$ × $20 \mathrm{~mm}$ (W x T x L) sections. These pieces were combined as pairs for the manufacturing of the glued test samples.

\section{Test Sample Manufacture}

For each species, three glued samples were prepared from each of the three surface machining treatments outlined in Table 1, resulting in nine glued test samples per species. 
Each glued sample was comprised of two $20 \mathrm{~mm}$ x $8 \mathrm{~mm}$ x $20 \mathrm{~mm}$ (W x T x L) pieces. The application of adhesive commenced within a maximum of 20 min after the surface machining. A one-component moisture-curing polyurethane (1C-PUR) adhesive (Jowat Jowapur 686.70) was used. This glue type is commercially used in structural glulam production in Australia. In order to provide sufficient contrast between the adhesive and the wood for imaging via MicroCT, iodine was added to the glue. Previous studies have demonstrated the usefulness of adding heavy atoms, e.g., iodine, to the adhesive for MicroCT studies with wood adhesives (Modzel et al. 2011; Paris 2014; Paris and Kamke 2015; Paris et al. 2015; Jakes et al. 2018). The added iodine increases the X-ray attenuation of the adhesive, which results in enhanced contrast between the adhesive and the wood cell walls (Jakes et al. 2018). The mixing of the glue with iodine was accomplished with an Elma S120 H Elmasonic ultrasonic dissolver (Singen, Germany) for a period of $30 \mathrm{~min}$ to $40 \mathrm{~min}$. The iodine concentration used was $5 \% \mathrm{~m} / \mathrm{m}$ for southern pine and $10 \% \mathrm{~m} / \mathrm{m}$ for spotted gum and Darwin stringybark. These concentrations were chosen based on the outcomes of preliminary screening which determined optimal concentrations to use for each species. In accordance with the technical data sheet for the adhesive, the 1C-PUR was applied at a spread rate of $250 \mathrm{~g} / \mathrm{m}^{2}(\mathrm{gsm})$. The open assembly time was less than $30 \mathrm{~s}$ and the closed assembly time was less than $5 \mathrm{~min}$. The samples were pressed at $0.9 \mathrm{MPa}$ for a minimum of 180 min under ambient conditions. After pressing, all the samples were then conditioned in a constant environment chamber set at a temperature of $20{ }^{\circ} \mathrm{C}$ and a $\mathrm{RH}$ of $65 \%$ (12\% EMC) for a minimum of $7 \mathrm{~d}$.

After conditioning, the samples were subjected to an accelerated weathering process. The weathering process was conducted in accordance with AS/NZS standard 1328.1:1998 (2011), which is used to test structural glulam bond performance in Australia. This accelerated weathering procedure is designed to test the bond integrity of the glued element by the introduction of a moisture gradient within the element (Vella et al. 2019). This induced an associated stress gradient with high tensile stresses perpendicular to the glue line, which will either result in the fracture of the timber lamella or a delamination of the glue lines if the bond strength is inadequate (Vella et al. 2019). Water impregnation of the samples was performed in a vacuum/pressure cylinder starting with total immersion of the test samples in water at $20^{\circ} \mathrm{C}$ and application of a vacuum at $-78 \mathrm{kPa}$, which was held for $5 \mathrm{~min}$. A pressure cycle of $550 \mathrm{kPa}$ for $1 \mathrm{~h}$ followed. While still immersed, the vacuum/pressure cycle was repeated, resulting in a two-cycle impregnation period. All samples were dried for $21 \mathrm{~h}$ at $65^{\circ} \mathrm{C}$, a RH that did not exceed $15 \%$, and with an air velocity of $2.4 \mathrm{~m} / \mathrm{s}$. This water impregnation and drying cycle was performed twice, as required by the AS/NZS 1328.1:1998 (2011) standard.

\section{MicroCT Imaging of the Samples}

The samples were scanned before and after the accelerated weathering cycling procedure described above via MicroCT. The samples were scanned at the Translational Research Institute (TRI) in Brisbane, Australia using a Bruker Skyscan 1272 (Bruker, Billerica, MA) set to a voltage of $60 \mathrm{kV}$ and a current of $166 \mu \mathrm{A}$. The scaled image pixel size was 21.32 microns.

\section{Glue Line and Adhesive Penetration Assessment}

To enable assessment of the glue line and adhesive penetration features, three image slices were selected from the MicroCT 3-D image dataset for each sample before and after undergoing the accelerated weathering process. The three slices targeted $25 \%, 50 \%$, and 
$75 \%$ of the sample length. Each image slice was then cropped to produce an image area showing $4 \mathrm{~mm}$ either side of the glue line for the full glue line length. Image J (IJ 1.46r) (National Institutes of Health, Bethesda, MD) was then used to measure the parameters described in Table 2 ( Schneider et al. 2012). The adhesive penetration and glue line thickness measurements (using Image $J$ ) were performed in terms of the contrast differences between the wood and the iodinated PUR adhesive using thresholding.

Table 2. Adhesive Bond Parameters

\begin{tabular}{|c|c|c|}
\hline Parameter & Description \\
\hline Bondline area & $\begin{array}{c}\text { Total surface area of the glue in the image area - including bulk adhesive } \\
\text { and adhesive penetration into wood (as a \% of the image area) }\end{array}$ \\
\hline $\begin{array}{c}\text { Glue line } \\
\text { thickness }\end{array}$ & $\begin{array}{c}\text { Region of the bondline containing only bulk adhesive between the lamella } \\
\text { surfaces, therefore not including adhesive penetration - measured at 10 } \\
\text { equally spaced intervals along the glue line length of the sample }\end{array}$ \\
\hline $\begin{array}{c}\text { Glue line } \\
\text { surface area }\end{array}$ & $\begin{array}{c}\text { Glue line surface area (as a \% of the image area) } \\
\text { Adhesive } \\
\text { penetration }\end{array}$ & $\begin{array}{c}\text { Interphase region of the bond line containing both adhesive and wood cells, } \\
\text { from the edge of the glue line to the extent of glue penetration into the wood } \\
\text { depths as well as the penetration surface area (as a \% of the image area) }\end{array}$ \\
\hline $\begin{array}{c}\text { Length of air } \\
\text { gaps/voids in } \\
\text { glue line length }\end{array}$ & $\begin{array}{c}\text { Linear extent of the air gaps or voids in the glue line (expressed as a \% of } \\
\text { glue line length }\end{array}$ \\
\hline $\begin{array}{c}\text { Adhesive } \\
\text { penetration into } \\
\text { wood structure }\end{array}$ & $\begin{array}{c}\text { Adhesive penetration into the wood structure in terms of its distribution into } \\
\text { different cell types }\end{array}$ \\
\hline
\end{tabular}

\section{Microscopy}

From three glued samples for each surface machining treatment for each species, thin glued wood sections (less than $60 \mu \mathrm{m}$ for southern pine and $8 \mathrm{~mm}$ thick for spotted gum and Darwin stringybark due to difficulties in preparing high quality thin sections from these high density hardwood species) were prepared for microscopic imaging. For southern pine, glass slides were prepared after the sections were stained with a safranin solution and then washed and dried using ethanol. For the hardwood samples, the images were taken from solid cross sections. Images of the sections for all species were captured using a Nikon Eclipse LV100ND microscope (Tokyo, Japan) with fluorescence lens at 50x and 100x magnification.

\section{Statistical Analysis}

Statistical analysis was carried out using GenStat v19 (VSN, Hemel Hempstead, United Kingdom). Analyses were performed independently for each species and included multi-strata analyses of variance. The first strata was a 1-way analysis comparing the 3 surface machining treatments (factor 1) with 9 independent replicates for each treatment. The second strata involved the pre- and post-measurements (factor 2) taken of the glue joints, before and after applying the wet and dry cycles, i.e., the accelerated 
weathering. In this part of the analysis, a test of the interaction between the 2 factors was also performed. When an analysis produced a significant treatment effect (or interaction), a Fisher's protected least significance t-test was used to compare the treatment means for significant differences at the $5 \%$ probability level.

\section{RESULTS AND DISCUSSION}

\section{Bondline Surface Area}

As shown in Fig. 1, there was a considerable loss in the amount of PUR adhesive, greater than $50 \%$ in some cases (indicated by a reduction in bondline surface area as a proportion of image area), from the glued samples after the accelerated weathering process for all three species. Overall, this effect was much greater in the hardwood species compared to southern pine, highlighting the poorer gluability of the hardwoods. The differences between pre- and post-accelerated weathering bondline areas (as a proportion of the image area) were statistically significant for spotted gum and Darwin stringybark ( $p$ value less than 0.001); however, they were not significantly different for southern pine. The observed reduction in amount of adhesive suggests that a proportion of the PUR adhesive is being washed out or detached from the wood during the accelerated weathering process.

In particular, the adhesive loss observed during accelerated weathering highlights the problem with successfully gluing spotted gum and Darwin stringybark for glulam. Figure 1 shows that for all three species, the amount of adhesive loss was much greater with samples that had been prepared via the planing surface machining treatment, followed by sanding post-planing, and then face milling, which had the lowest level of adhesive loss after the accelerated weathering process.

The significant differences between treatments in terms of bondline areas are shown in Fig. 1, which highlighted that for all species, as well as for pre- and post-accelerated weathering, planing resulted in significantly smaller bondline areas compared to face milling and sanding post-planing. Luedtke et al. (2015) also showed that face milling resulted in an increased bondline area in studies on European timbers, e.g., ash, beech, oak, and Norway spruce. The planing treatment also resulted in the lowest tensile shear strength for lap shear samples, as reported in related work by Leggate et al. (2021a,b), with face milling and sanding post-planing producing superior results. The improved glue bonds produced by face milling and sanding post planing in these related studies were attributed to differences in surface roughness, fibrillation, and the magnitude of sub-surface damage (Leggate et al. 2021a,b). Figure 1 also shows that face milling resulted in greater bondline areas in all cases, with the exception of the pre-accelerated weathering spotted gum samples, where sanding post-planing had the highest bondline area. Figure 2 provides a visual example of the adhesive loss that occurred after accelerated weathering; in this case, showing spotted gum glued samples that were prepared via the planing surface machining treatment before gluing.

Bondline areas were also much greater in southern pine samples compared to the two hardwood species, for both pre- and post-accelerated weathering data. This was despite all samples receiving equivalent adhesive spread rates during sample preparation. The greater bondline area in southern pine is linked to the greater adhesive penetration and associated higher resistance to adhesive squeeze-out in this species, which is discussed below. 

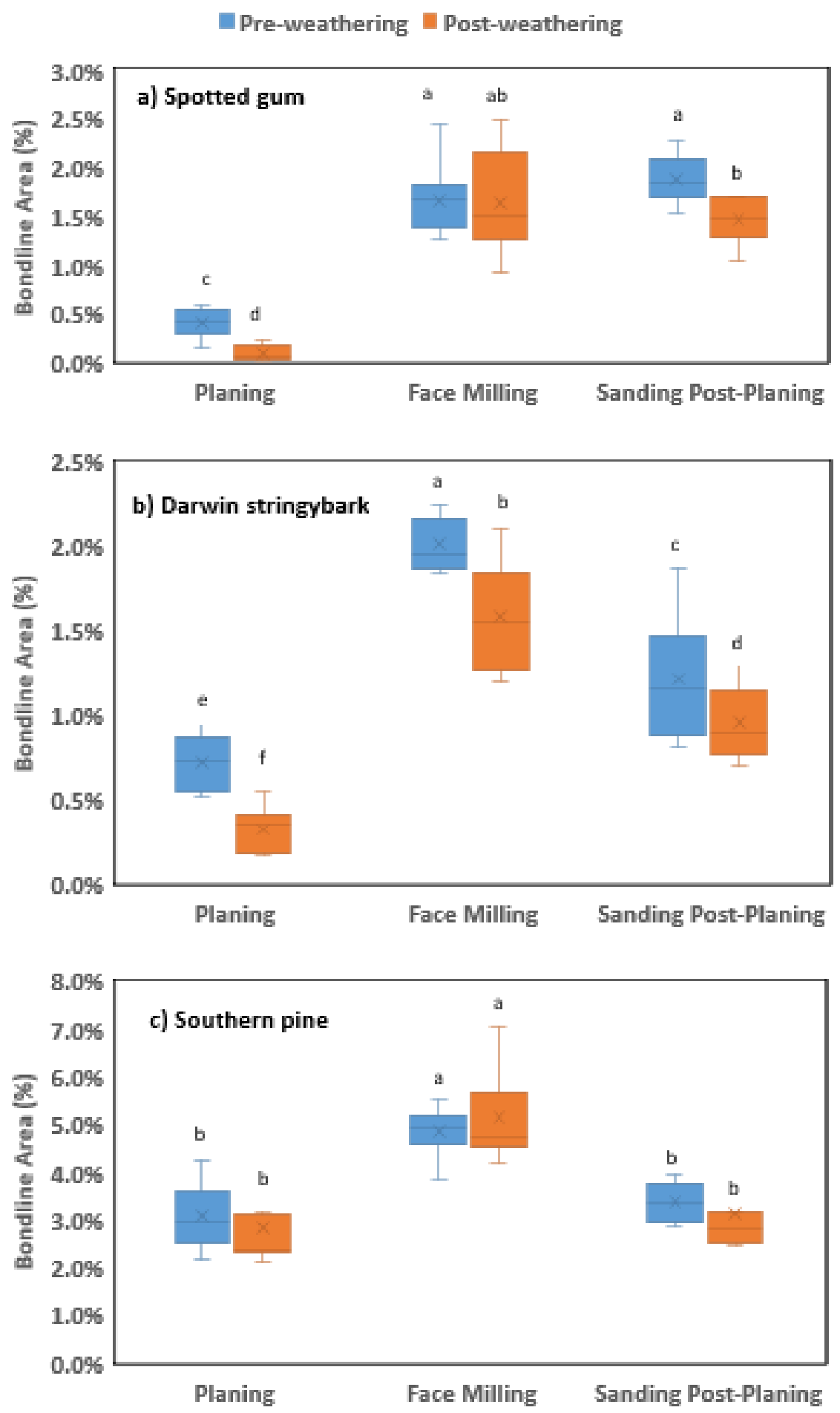

Fig. 1. Bondline area for pre- and post-weathering a) spotted gum; b) Darwin stringybark; and c) southern pine samples (means $(x)$ with the same letter within each graph are not significantly different) 


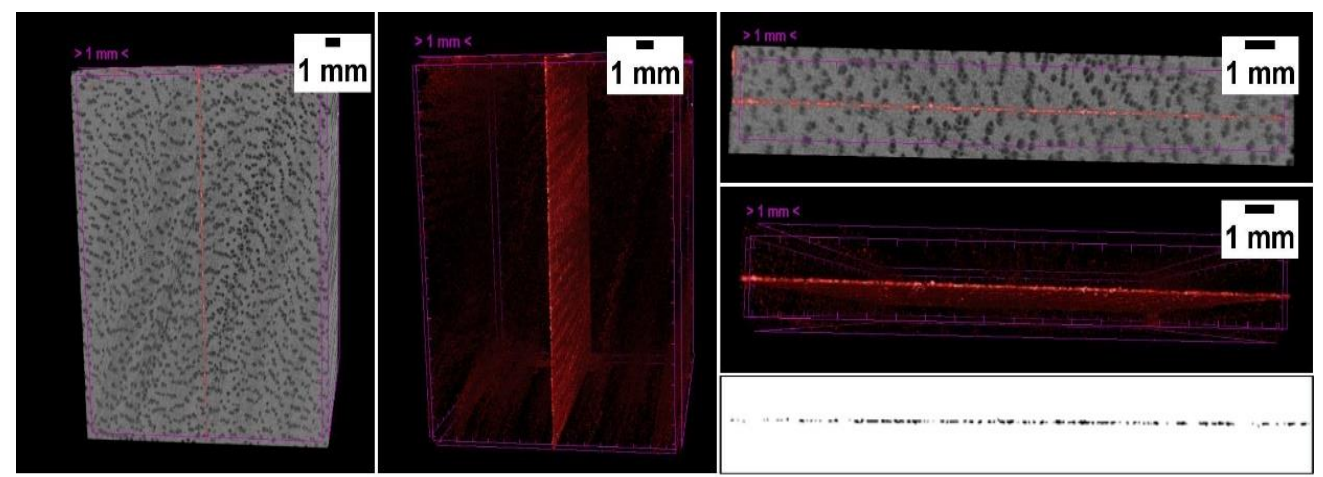

(a)

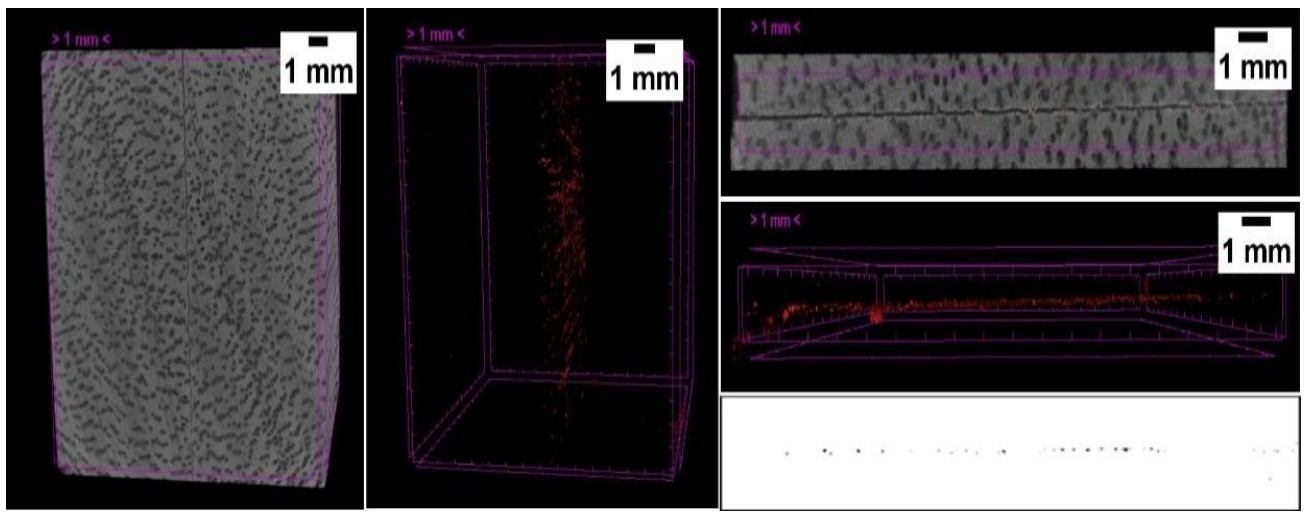

(b)

Fig. 2. Images of the bondline pre (a) and post (b) accelerated weathering for spotted gum with a sample prepared by planing (white scale bar $=1 \mathrm{~mm}$ )

Face milling has been shown to result in increased fibrillation and a greater exposure of open cell lumens, which increases the actual surface available for mechanical anchorage of adhesives as well as increasing adhesive penetration (Cool and Hernández 2011). This feature of face milling could explain the trend of greater bondline areas with face milling as well as the generally increased resistance to adhesive loss during accelerated weathering that was observed in this study.

Further studies need to be undertaken with these species on the adhesive loss after accelerated weathering discussed above. In particular, these studies should investigate the effect of the iodine on the adhesive properties and also the integrity of the iodine during the accelerated weathering process. It is possible that the addition of iodine to the PUR adhesive may be associated with the reported loss in adhesive after accelerated weathering.

\section{Air Gaps/Voids in the Glue Line}

Figures 3 and 4 show that there was an extremely high frequency of air gaps or voids in the glue lines for all three species and for all surface machining treatments, with mean void percentages (as a percentage of the glue line length) across all species and surface machining treatments ranging from $21 \%$ to $99 \%$. This was evident at both pre- and post-accelerated weathering examinations; however, voids in the glue lines significantly increased ( $p$-value less than 0.001) for all species after accelerated weathering, which was linked to the washing out or loss of adhesive. 

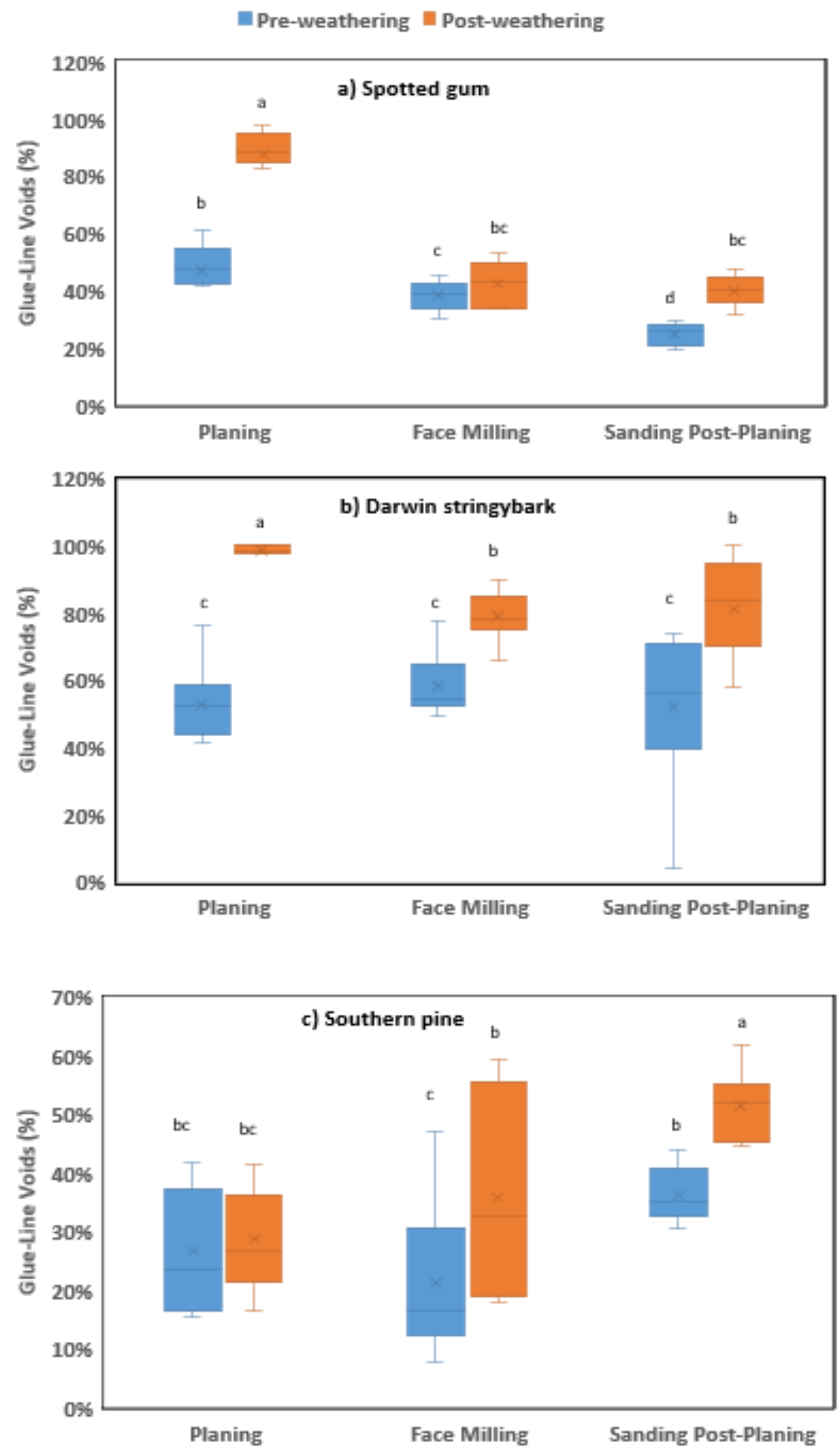

Fig. 3. Glue line voids for pre- and post-weathering a) spotted gum; b) Darwin stringybark; and c) southern pine samples (means $(x)$ with the same letter within each graph are not significantly different)

There was a higher frequency of voids in the glue lines of both hardwood species compared to southern pine, again likely to be linked to the poorer gluability of these species. In the hardwood species, planing produced a significantly higher percentage of voids ( $p$-value less than 0.05 ) in the glue lines after the accelerated weathering process; 
however, there were no significant differences between face milling and sanding postplaning. For the southern pine samples, sanding post-planing produced a significantly ( $p$ value less than 0.05 ) higher percentage of glue line voids for post-accelerated weathering data compared to face milling and planing. Significant differences in the percentage of glue line voids between the surface machining treatments are shown in Fig. 3 for the three species, both pre- and post-accelerated weathering. This further highlights differences in the effects of each surface machining treatment.
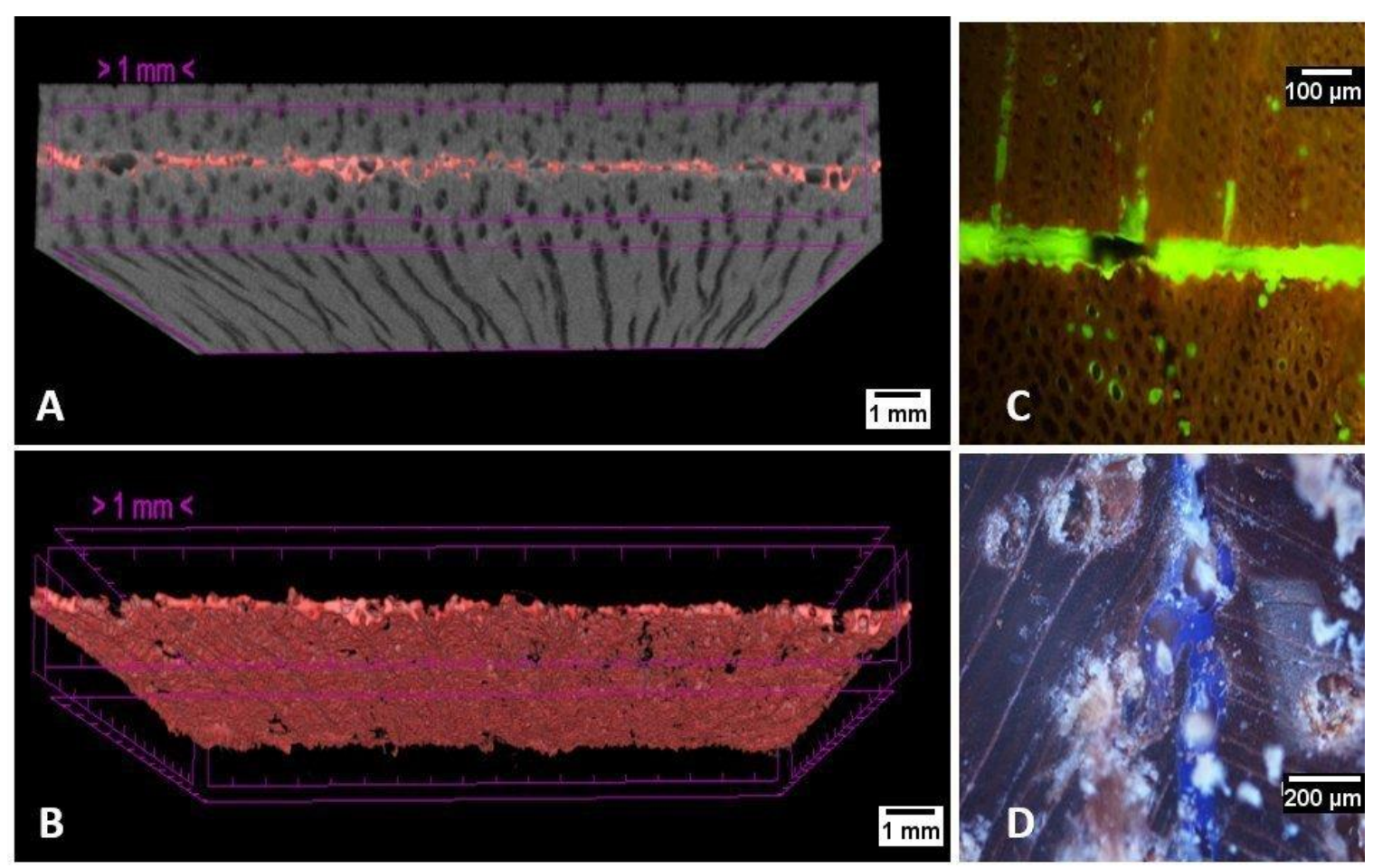

Fig. 4. Glue line voids in PUR glue lines: A) MicroCT (3D) image of spotted gum glue line (red) and wood; B) MicroCT (3D) images of spotted gum glue line only (red); microscopy images of glue lines for C) southern pine; and D) Darwin stringybark (Note: for $A$ and $B$ the scale is $1 \mathrm{~mm}$, for $C$ the scale is $100 \mu \mathrm{m}$, and for $D$ the scale is $200 \mu \mathrm{m}$ )

A possible explanation for the higher incidence of glue-line voids after accelerated weathering with planing compared to the other surface machining treatments for the two hardwood species is that there were differences in adhesive bond quality resulting from differences in surface roughness, fibrillation, and sub-surface damage. The higher wood surface roughness and fibrillation associated with the face milling and sanding post-planing surface machining treatments may be contributing to the reduction in glue line voids through improved adhesive bond quality and increased resistance to wash out. These effects derive from an increased surface area for mechanical adhesion and an increased exposure of hydrophilic sites for the adhesive to bond to. However, it is unclear why the sanding post-planing treatment generated a significantly higher glue line void percentage in southern pine compared to the other surface machining treatments. Further studies need to be undertaken to explain the reasons for the differences in glue line void percentage between surface machining treatments for both pre- and post-weathering data.

Voids in the cured adhesive are expected to reduce the adhesive bond strength and durability, such that minimizing or eliminating air bubbles is essential to achieving the strongest bond (Sage and Tiu 1982; Duhamel 2016; Permabond 2021a). The high 
frequency of voids in the PUR glue lines for all three species in this study has also been observed in unpublished studies by the authors using RF adhesives with spotted gum and Darwin stringybark. Figure 5 shows voids in the RF glue lines of spotted gum. This high frequency of voids in the glue lines of these species is likely to be a key factor in limiting bond performance. Voids in cured adhesives can be caused by a number of factors, which can vary depending on the adhesive type and process. Possible sources of the voids include air entrapment in the adhesive during the mixing and application process; chemical reactions and emissions, e.g., the reaction of PUR adhesives with water, which generates carbon dioxide gas bubbles; fillers, which may have micro-air bubbles attached to their surface; excessive shrinkage of the adhesive during hardening; and insufficient adhesive in the glue line (Sage and Tiu 1982; Hass et al. 2012; Bastani et al. 2016; Duhamel 2016; Dugmore 2018; Permabond 2021b).

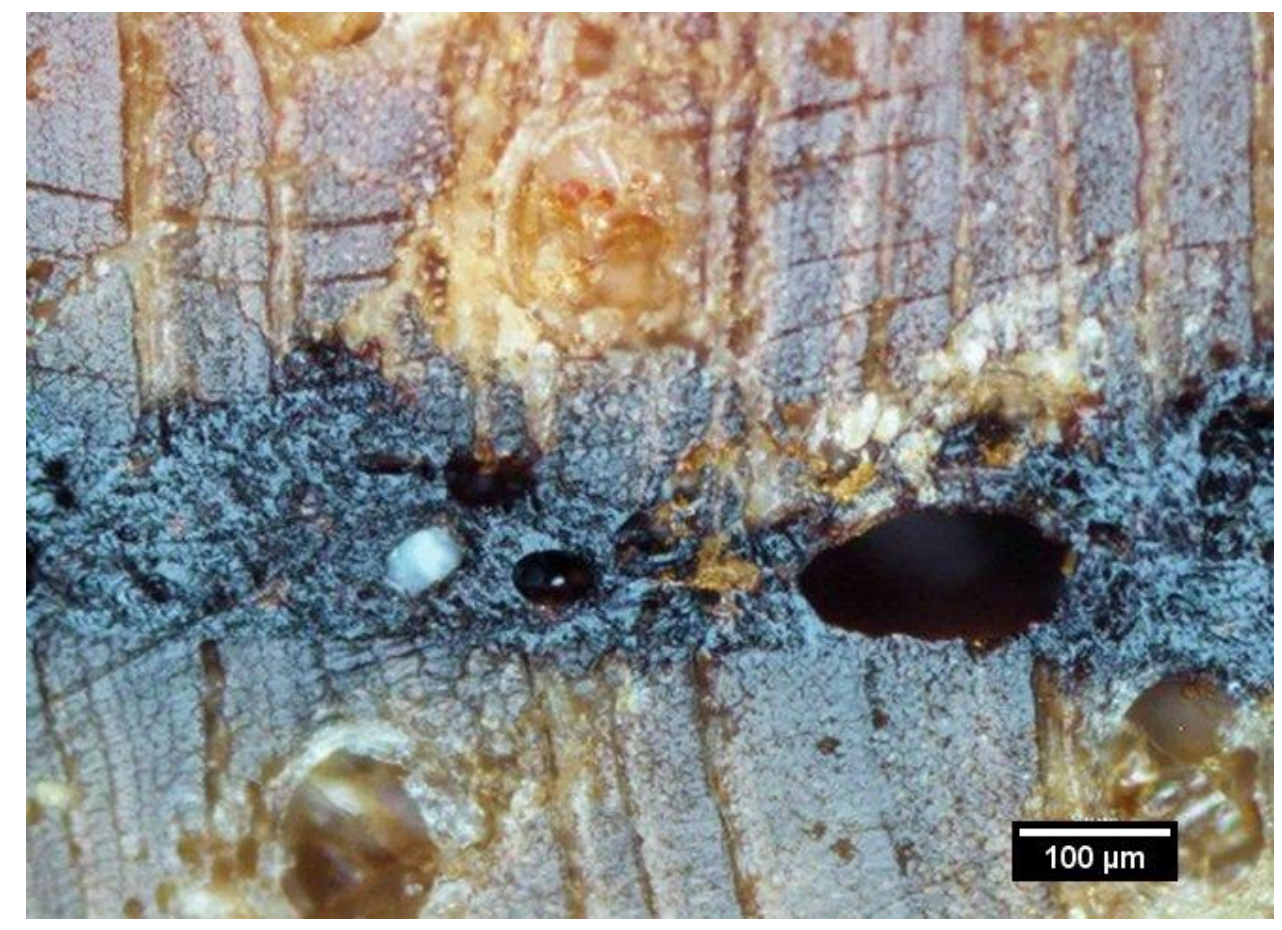

Fig. 5. Glue line voids in the RF glue line in spotted gum, which also shows tyloses and other occlusions in vessels limiting penetration (scale is $100 \mu \mathrm{m}$ )

\section{Glue Line Thickness and Surface Area}

The technical data sheet for the Jowat 686 series 1C PUR used in this study suggests an optimal glue line thickness of approximately $0.1 \mathrm{~mm}$, and a maximum recommended glue line thickness of $0.3 \mathrm{~mm}$. Table 3 illustrates that the glue line thickness in the study samples were mostly within this range for all three species and surface machining treatments, with the exception of the face milling treatment for southern pine, which resulted in glue line thicknesses that slightly exceeded this range (mean of $0.33 \mathrm{~mm}$ ).

For all three species, face milling produced the thickest glue lines and greatest total glue line surface area (as shown in Table 3, Fig. 6, and Fig. 7), followed by sanding postplaning, and planing, which had the thinnest glue lines. 

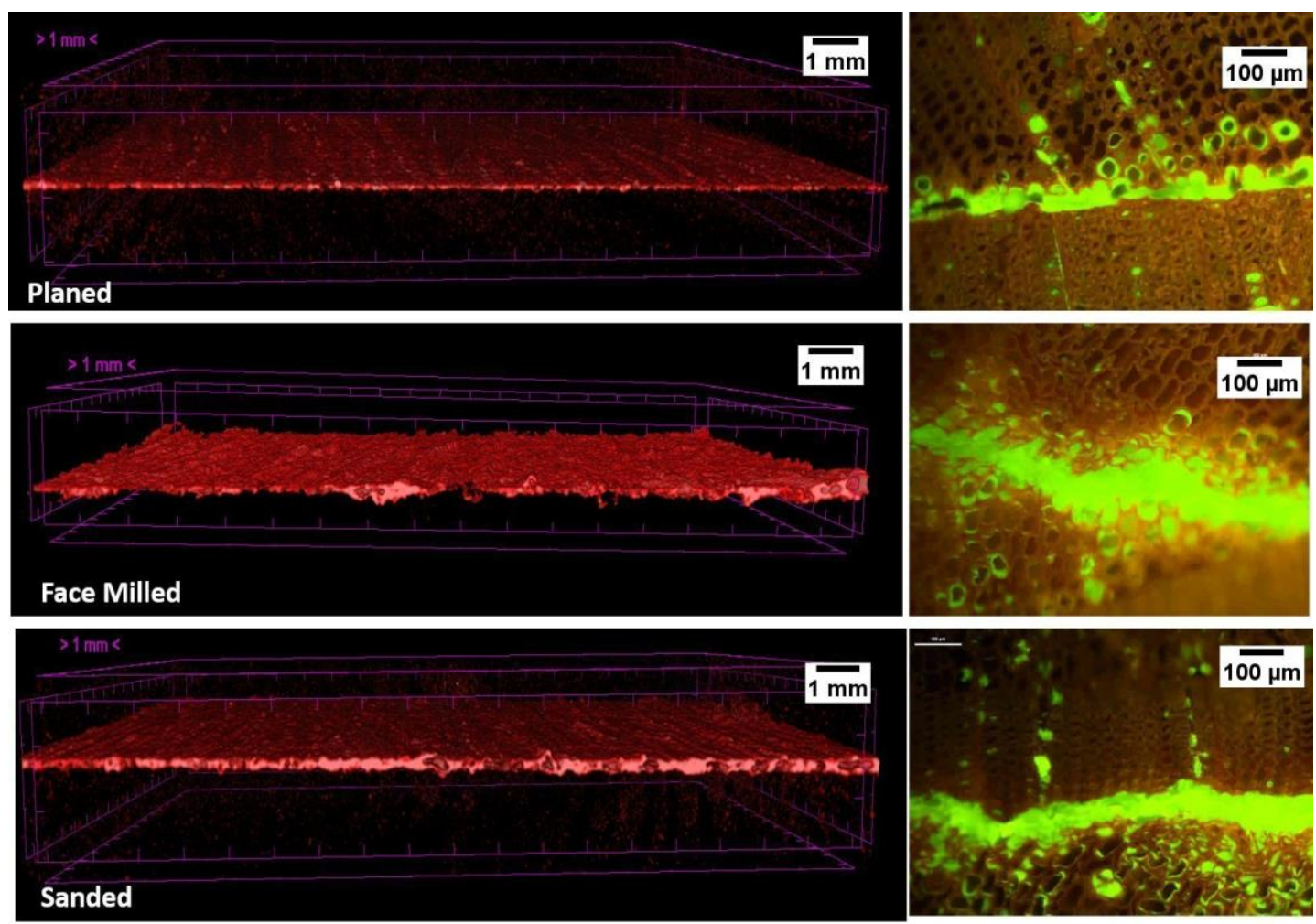

Fig. 6. Glue line morphology differences for each surface machining treatment for southern pine planing (top left and right), face milling (middle left and right), and sanding post-planing (bottom left and right) (Note: for the MicroCT images on the left the scale is $1 \mathrm{~mm}$ and for the microscopy images on the right the scale is $100 \mu \mathrm{m}$ )

Face milling and sanding post-planing resulted in significantly higher surface roughness in studies reported by Leggate et al. (2021b) and also produced better results in terms of tensile shear strength for lap shear samples in related studies by Leggate et al. $(2021 \mathrm{a}, \mathrm{b})$. The glue line thickness and surface area was higher for all the southern pine surface machining treatments compared to the two hardwood species. The resultant glue line thickness is usually a function of adhesive type and properties, adhesive spread rates, wood characteristics (including surface preparation, adhesive process parameters (including open and closed assembly times), press pressures and press time, adhesive penetration, and squeeze-out. Given that in this study, the adhesive characteristics and adhesive process parameters were kept constant, differences in the glue line thickness between species and surface machining treatments reflect differences in the magnitude of adhesive squeeze-out during the gluing process and adhesive penetration (as discussed below). The thicker glue lines (as well as increased penetration - discussed below) produced from face milling in this study suggests that for these species, face milling results in wood surfaces which are more resistant to adhesive squeeze-out during the gluing process.

For all three species, for the combined data across all surface machining treatments, the glue line thickness and surface area significantly decreased after undergoing accelerated weathering (a $p$-value less than 0.001 for spotted gum and Darwin stringybark glue line surface area, a $p$-value less than for spotted gum glue line thickness, a $p$-value less than 0.01 for Darwin stringybark glue line thickness, and a $p$-value less than 0.05 for southern pine glue line surface area and thickness). 

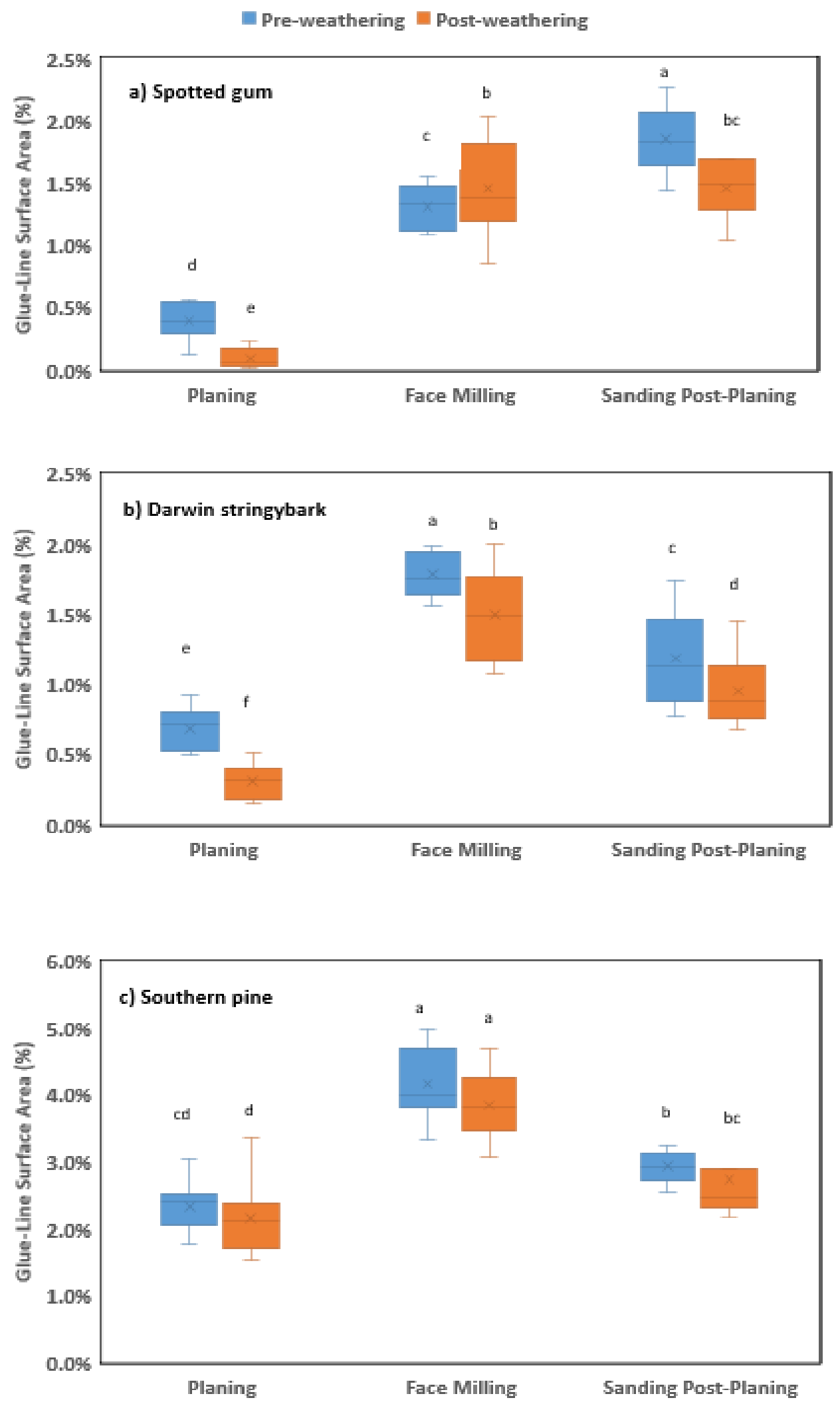

Fig. 7. Glue line surface area for pre- and post-weathering a) spotted gum; b) Darwin stringybark; and c) southern pine (means $(x)$ with the same letter within each graph are not significantly different) 
The reduction in glue line area indicates an overall loss of adhesive occurring during the accelerated weathering process, which is discussed above. However, for the two hardwood species that received the face milling surface treatment, there was no reduction in glue-line surface area after undergoing accelerated weathering.

There was also a notable difference in the morphology of the glue lines between the different surface machining treatments. The planing surface machining treatment produced smoother, linear, and flat glue lines, whereas the face milling and sanding postplaning resulted in more undulating and uneven thickness glue lines (as shown in Fig. 6). Similar differences in the topography of the glue lines between the planing and face milling methods have been observed in other studies (Cool and Hernández 2011; Luedtke et al. 2015). Statistically significant differences in the glue line thickness and the glue line surface area between the surface machining treatments are shown in Table 3 and Fig. 7. This further highlights the differences in the effects of each surface machining treatment for the three species, for both pre- and post-accelerated weathering samples.

Table 3. Summary of Glue line Thickness

\begin{tabular}{|c|c|c|c|c|}
\hline \multirow{2}{*}{$\begin{array}{l}\text { Pre or Post } \\
\text { Weathering }\end{array}$} & \multirow{2}{*}{$\begin{array}{l}\text { Surface Machining } \\
\text { Method }\end{array}$} & \multicolumn{3}{|c|}{ Mean Glue line Thickness (mm) } \\
\hline & & Spotted gum & Darwin stringybark & Southern pine \\
\hline \multirow{4}{*}{ Pre } & Planing & $0.10(0.01) \mathrm{d}$ & $0.12(0.01) \mathrm{c}$ & $0.15(0.02) d$ \\
\hline & Face Milling & $0.25(0.02) a$ & $0.27(0.02) \mathrm{a}$ & $0.33(0.04) a$ \\
\hline & Sanding Post-Planing & $0.20(0.02) b$ & $0.19(0.02) b$ & $0.25(0.02) b$ \\
\hline & Combined & $0.18(0.06)$ & $0.19(0.07)$ & $0.24(0.08)$ \\
\hline \multirow{4}{*}{ Post } & Planing & $0.06(0.02) \mathrm{e}$ & $0.09(0.01) d$ & $0.14(0.03) d$ \\
\hline & Face Milling & $0.20(0.03) b c$ & $0.26(0.04) \mathrm{a}$ & $0.33(0.04) a$ \\
\hline & Sanding Post-Planing & $0.18(0.02) \mathrm{c}$ & $0.17(0.03) b$ & $0.22(0.02) \mathrm{c}$ \\
\hline & Combined & $0.15(0.07)$ & $0.17(0.07)$ & $0.23(0.08)$ \\
\hline
\end{tabular}

\section{Adhesive Penetration}

Adhesive penetration, as a proportion of the image area, is shown in Fig. 8. For the hardwood species, face milling resulted in the greatest adhesive penetration, followed by sanding post-planing, and planing. The results for the adhesive penetration in these two species match the permeability results in related studies reported by Leggate et al. (2020, 2021b), where face milling resulted in the highest permeability, followed by sanding postplaning, and then planing with the lowest permeability. The differences in adhesive penetration between the three surface machining treatments are likely explained by the same factors that resulted in permeability differences, which are discussed by Leggate et al. (2020, 2021b); these differences are primarily attributed to the impact of these treatments on the surface topography and wood anatomy. The planing surface machining method is known to create more sub-surface damage and a less intact wood structure 
compared to face milling (Kläusler et al. 2014). This sub-surface damage includes cell compaction, crushing, and distortion, which is expected to impede gas and liquid movement into the wood, potentially causing the lower permeability and adhesive penetration (Leggate et al. 2021b). The sanding post-planing would also be expected to have similar sub-surface damage to the planing method. However, the sanding treatment will create a rougher surface, which may increase the surface area for gas and liquid penetration into the wood. It may also remove some of the compacted and damaged wood, possibly explaining the increased permeability and adhesive penetration compared to the planing method (Leggate et al. 2021b). The face milling method results in limited subsurface damage, as well as the added advantage of increased fibrillation, which is likely to result in improved permeability and adhesive penetration (Leggate et al. 2021b). The differences in adhesive penetration between face milling and planing and between face milling and sanding post-planing were significant for both spotted gum and Darwin stringybark ( $p$-value less than 0.05). Cool and Hernández (2011) also showed that face milling resulted in deeper adhesive penetration compared to other surface machining treatments in a study on black spruce (Picea mariana) wood. However, in the current study, there were no significant differences in total penetration area between surface machining treatments for southern pine.

Penetration was much greater in southern pine compared to spotted gum and Darwin stringybark, as shown in Figs. 8 and 9. As a percentage of the image area averaged for all surface machining treatments, penetration was only $0.13 \%$ and $0.10 \%$ for spotted gum and Darwin stringybark, respectively, compared to $0.63 \%$ for southern pine. The mean maximum penetration depth is also shown in Table 4 , showing that for the combined surface machining group data for spotted gum, the adhesive penetration value did not exceed $0.35 \mathrm{~mm}$ and for Darwin stringybark, the maximum penetration was $0.44 \mathrm{~mm}$. For southern pine, the mean maximum penetration depth was $2.01 \mathrm{~mm}$. This reflects the extremely impermeable nature of spotted gum and Darwin stringybark compared to southern pine, as discussed by Leggate et al. (2020, 2021a,b). Redman et al. (2016) also reported extremely low permeability in spotted gum, highlighting its much lower porosity compared to other species. Spotted gum and Darwin stringybark are also characterized by vessels in the heartwood containing abundant tyloses and extractives deposition, which impedes the movement of gases and liquids (Dadswell 1972; Queensland Government 2021) (as shown in Figs. 5 and 11). Figure 9 illustrates the differences in penetration between the southern pine and spotted gum samples.

Table 4. Summary of Adhesive Penetration Depth

\begin{tabular}{|c|c|c|c|}
\hline \multirow{2}{*}{$\begin{array}{c}\text { Surface Machining } \\
\text { Method }\end{array}$} & \multicolumn{3}{|c|}{ Mean Maximum Penetration Depth (mm) } \\
\hline & Spotted gum & Darwin stringybark & Southern pine \\
\hline Planing & $0.51(0.81) \mathrm{a}$ & $0.77(0.38) \mathrm{a}$ & $2.82(1.12) \mathrm{a}$ \\
\hline Face Milling & $0.41(0.24) \mathrm{a}$ & $0.43(0.51) b c$ & $1.71(0.65) b c$ \\
\hline Sanding Post-Planing & $0.14(0.03) \mathrm{a}$ & $0.12(0.09) \mathrm{c}$ & $1.49(0.48) b c$ \\
\hline Combined & $0.35(0.49)$ & $0.44(0.45)$ & $2.01(0.97)$ \\
\hline
\end{tabular}

Leggate et al. (2021). "Examining wood via MicroCT," BioResources 16(3), 5058-5082. 

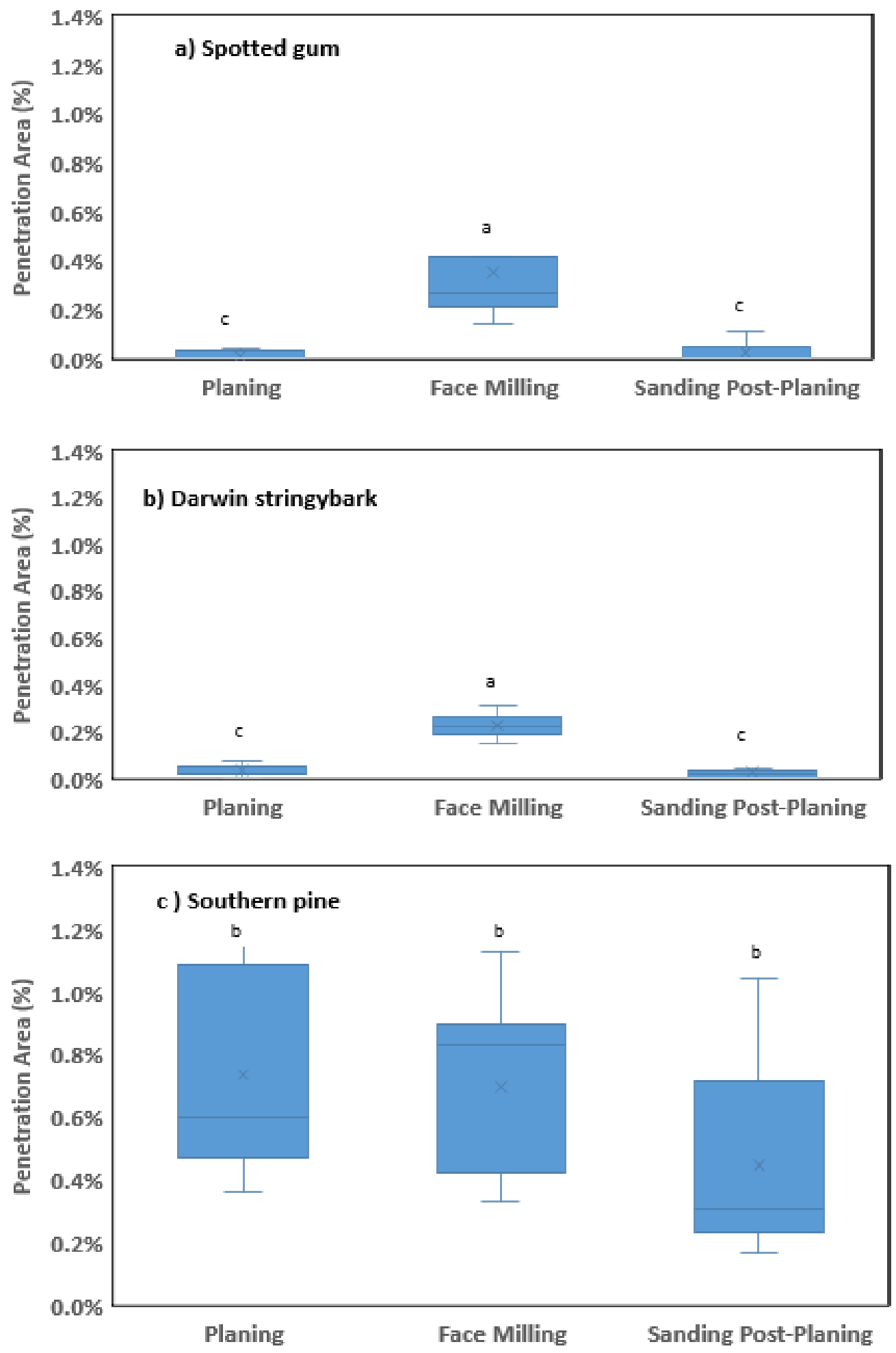

Fig. 8. Penetration area for spotted gum, Darwin stringybark, and southern pine (means $(x)$ with the same letter within each graph are not significantly different) 

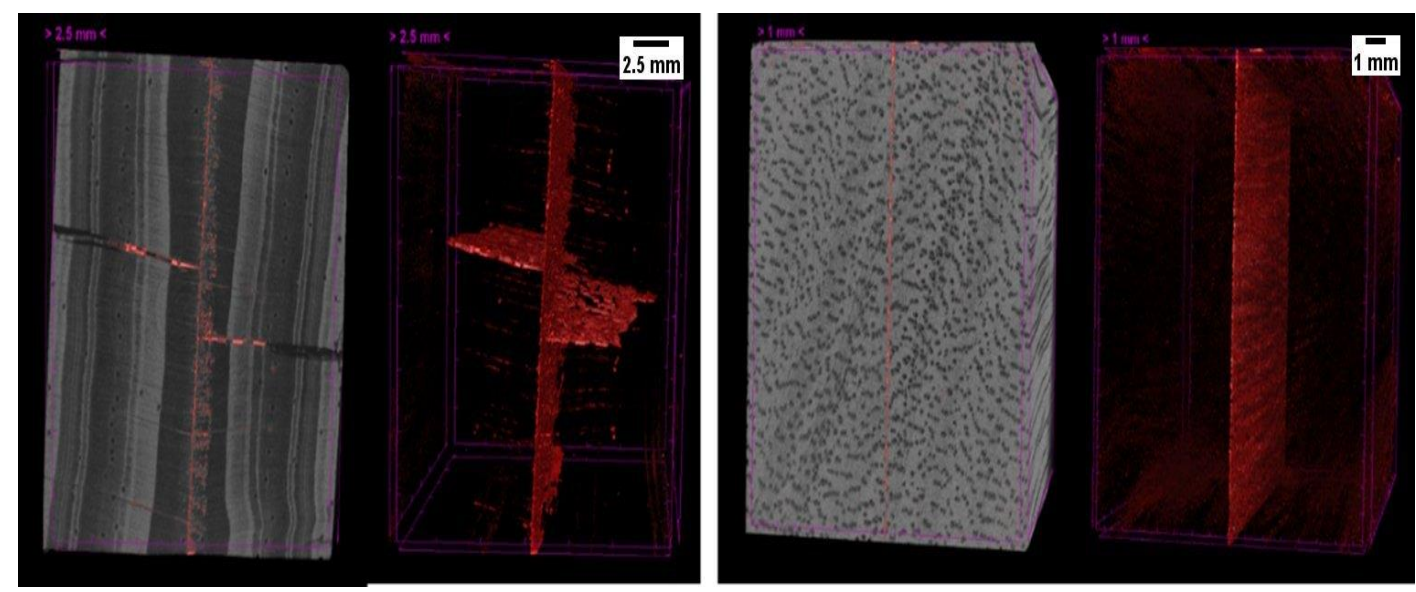

Fig. 9. MicroCT (3D) images showing the differences in adhesive penetration between southern pine and spotted gum; the left image is southern pine and the right image is spotted gum (Note: for the MicroCT images on the left the scale is $2.5 \mathrm{~mm}$ and for the images on the right the scale is $1 \mathrm{~mm}$ )

Given the typical sizes of anatomical elements in wood, a higher resolution for MicroCT imaging than that used in this study would facilitate a clearer distinction between wood features and the location of the adhesive. However, the drawback in using higher resolution with MicroCT is the reduced field of view and potential requirement for smaller sized samples.

\section{Observations on Adhesive Penetration into Wood Cellular Structure}

In southern pine, the adhesive penetrated into the earlywood and latewood tracheids, rays, and resin canals.

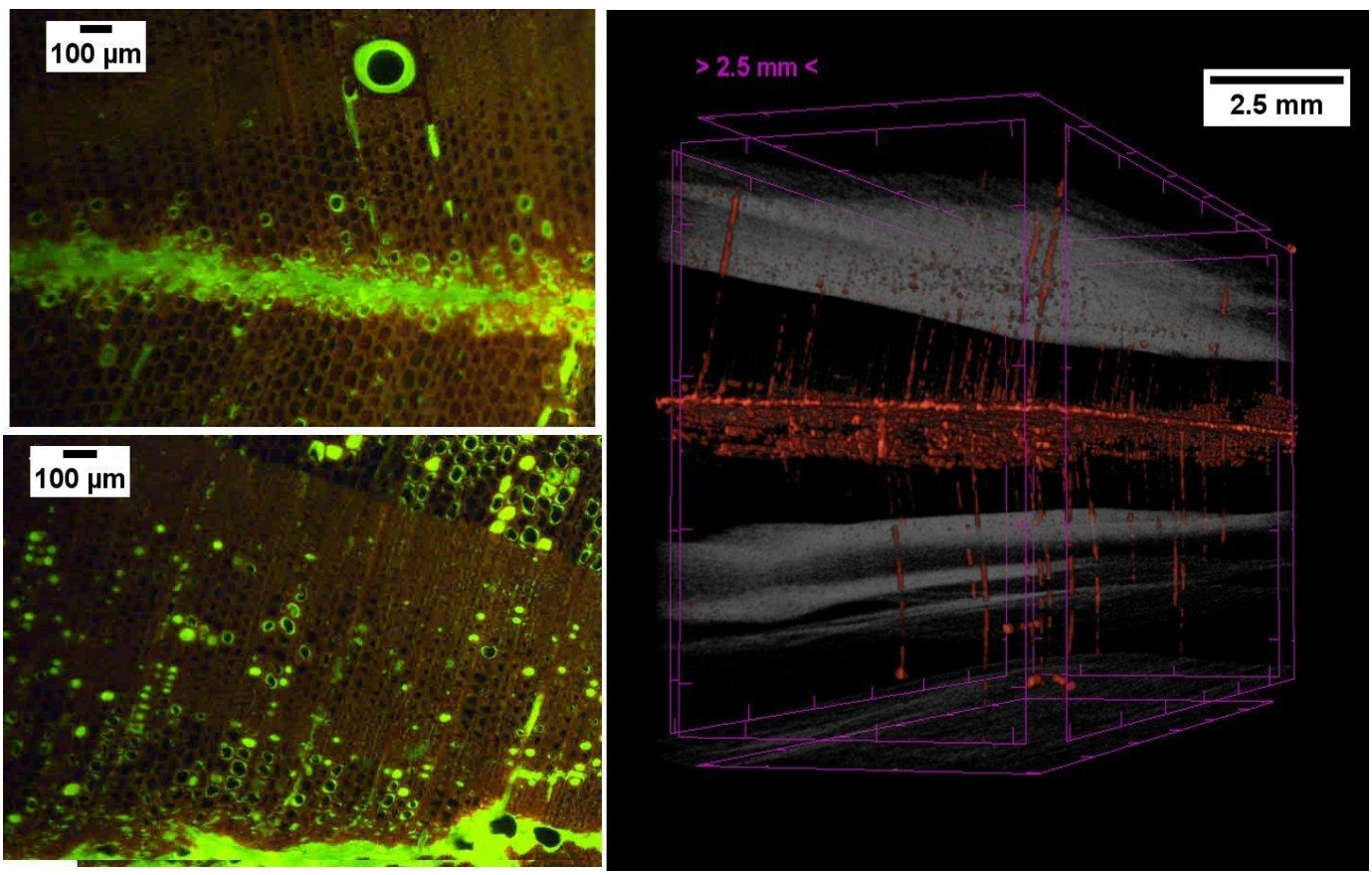

Fig. 10. Glue penetration features in southern pine showing the ring of adhesive around the axial resin canals and differential penetration into earlywood and latewood (Note: for the microscopy images on the left the scale is $100 \mu \mathrm{m}$; for the MicroCT images on the right the scale is $2.5 \mathrm{~mm}$ ) 
Penetration into the earlywood tracheids was more pronounced than into the latewood tracheids, with a penetration depth typically from 1 cell to 8 cells from the glue line into the earlywood tracheids (as shown in Fig. 10). Occasionally, the adhesive was observed to penetrate first through the rays and then from the rays into the earlywood and latewood tracheids distant from the glue line. The higher penetration of the adhesive into the earlywood compared to the latewood is most likely related to the significantly higher wettability of earlywood compared to latewood, as reported by Leggate et al. (2020, 2021c). Other studies have also reported higher wettability and greater adhesive penetration of earlywood compared to latewood (Herczeg 1965; Hse 1968; White 1977; Brady and Kamke 1988; Scheikl and Dunky 1998; Paris et al. 2015; Qin et al. 2017). Differences between the wettability and adhesive penetration of earlywood and latewood have been attributed to the larger lumen diameter, lower density, and higher porosity of earlywood compared to latewood (Scheikl and Dunky 1998; Frihart 2013; Paris et al. 2015; Qin et al. 2017). Adhesive penetration into the rays was deeper than into the tracheids. Both the horizontal and vertical resin canals appeared to be major conduits for adhesive movement. Rings of adhesive could be observed around the axial resin canals (as shown in Fig. 10). In all species, markedly deeper penetration was observed where there were surface checks (or cracks) in the wood.

In contrast to the southern pine, the adhesive penetration in spotted gum and Darwin stringybark was minimal (in most cases less than 1 vessel from the glue line). In addition, it was much more difficult to discern and was primarily confined to the vessels (as shown in Fig. 11).
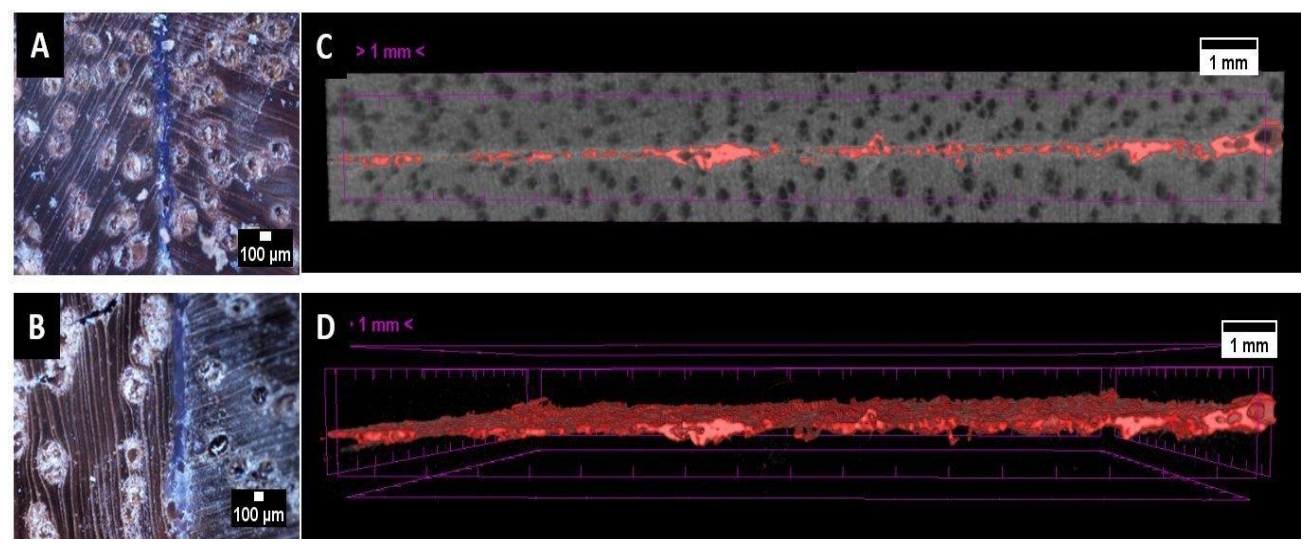

Fig. 11. Glue penetration features in Darwin stringybark $(A)$ and in spotted gum (B, $C$ and $D)$, showing minimal penetration away from the glue line and a high frequency of tyloses and other occlusions in vessels (Note: for the microscopy images on the left the scale is $100 \mu \mathrm{m}$ and for the MicroCT images on the right the scale is $1 \mathrm{~mm}$ )

Diffuse porous hardwoods, e.g., spotted gum and Darwin stringybark, are made up of vessels, tracheids, fibres, and axial and radial parenchyma (Crafford 2013; Dugmore 2018). Studies have shown that in diffuse porous hardwoods, as well as other hardwoods, vessels are the most important elements in terms of adhesive flow (Kamke et al. 2007; Bastani et al. 2016; Dugmore 2018; Pröller et al. 2018). This is because vessels typically have much larger lumen diameters compared to other cell types, and vessels are the primary conduits for fluid flow in hardwood trees. Other hardwood cell types, e.g., fibres, are less suitable for wood adhesive penetration because their main function is structural support; as 
such, they have narrower lumens and thicker cell walls that diminish adhesive flow (Bastani et al. 2016). However, in the heartwood of spotted gum and Darwin stringybark, the vessels are often occluded by tyloses and extractives, which impede fluid flow and lead to exceptionally low porosity (Dadswell 1972; Queensland Government 2021) (as shown in Figs. 5 and 11). Studies by Leggate et al. (2020, 2021b) highlighted the extremely low permeability of spotted gum and Darwin stringybark timber, which is one explanation for the minimal adhesive penetration observed in these species.

\section{CONCLUSIONS}

1. There was a considerable loss or washing out of the adhesive, as well as major reductions in bondline areas from the glued samples, after undergoing the accelerated weathering process for all three species. The adhesive loss and reduction in bondline areas was greatest in the two hardwood timbers, compared to southern pine, highlighting their differences in gluability.

2. For all three species, face milling and sanding post-planing treatments experienced lower adhesive loss during accelerated weathering compared to planing, and for preand post-accelerated weathering, planing also resulted in significantly smaller bondline areas compared to face milling and sanding post-planing. The greater resistance to adhesive loss and increased bondline areas of face milling and sanding post-planing are linked to improved tensile shear strength, as demonstrated by the results of related studies with the same three species. These improvements are attributed to differences in surface roughness, fibrillation, and the magnitude of sub-surface damage. The bondline areas were also much greater for southern pine compared to the two hardwood species, reflecting the differences in the adhesive penetration and resistance to squeezeout during the gluing process.

3. There was an extremely high frequency of air gaps or voids in the glue lines for all three species as well as for all three surface machining treatments, which would negatively impact bond strength and durability. This was evident for both pre- and postaccelerated weathering results. However, voids in the glue lines significantly increased for all species after undergoing accelerated weathering, which linked to the washing out or loss of adhesive during this process. There was a higher frequency of voids in the glue lines of both hardwood species compared to southern pine, likely to be linked to the poorer gluability and permeability of the hardwood species by comparison. In the hardwoods, planing produced a significantly higher percentage of voids in the glue lines after undergoing the accelerated weathering process in comparison to the face milling and sanding post-planing samples. For southern pine, sanding post-planing produced a significantly higher percentage of glue lines voids in comparison to the face milling and planing. The voids in the glue line may be a consequence of several factors including $\mathrm{CO}_{2}$ gas generation, air entrapment during the mixing and application process, and loss of adhesive during the accelerated weathering process.

4. For all three species, face milling produced the thickest glue lines, followed by sanding post-planing, and then planing. The glue line thickness was higher in southern pine compared to the two hardwood species. For all three species, the glue line thickness significantly decreased after the samples underwent accelerated weathering. The

Leggate et al. (2021). "Examining wood via MicroCT," BioResources 16(3), 5058-5082. 
planing surface machining treatment produced smoother, linear, and flat glue lines, whereas the face milling and sanding post-planing resulted in more undulating and uneven glue lines.

5. For the hardwood species, face milling resulted in the greatest adhesive penetration, followed by sanding post-planing, and then planing, with the lowest amount of penetration. For southern pine, there were no significant differences in the penetration area between surface machining treatments. Adhesive penetration was much greater in southern pine compared to spotted gum and Darwin stringybark.

6. In southern pine, the adhesive penetrated into the earlywood and latewood tracheids, rays, and resin canals. Penetration into the earlywood tracheids was much more pronounced than into the latewood tracheids. In contrast to the southern pine, the adhesive penetration in spotted gum and Darwin stringybark was very minimal (in most cases less than 1 vessel from the glue line) and much more difficult to discern as well as being primarily confined to the vessels.

7. Overall, for all species, the results highlight the larger bondlines, thicker glue lines, and greater resistance to adhesive wash-out with timber that was prepared via face milling compared to planing. This supports the results from recent related studies using the same timber species, where face milling also resulted in significantly higher tensile shear strength compared to planing. For the two hardwood species, face milling also resulted in greater adhesive penetration. However, for southern pine, there were no significant differences in the adhesive penetration between the three surface machining treatments.

\section{ACKNOWLEDGMENTS}

The authors are particularly grateful for the technical support of Mrs. Rica Minett, Mr. Dan Field, and Mr. Eric Littee with the preparation, processing, and testing of the wood samples. Mr. Bob Mayer is thanked for his assistance with statistical analysis. Mr Kamil Sokolowski is acknowledged for his very generous assistance and guidance with the MicroCT component of the project. The authors are also grateful to the Robertson Brothers Sawmill, DTM Timber, and Hyne Timber, for the supply of the wood used for this project. Mr. Shane Deveraux and Mr. Rod Vella from Jowat Universal Adhesives Australia Pty Ltd are also thanked for the provision of the adhesive used in the study. The ARC Training Centre for M3D Innovation is acknowledged for supporting this study. The support provided by the Queensland Government, Department of Agriculture and Fisheries (DAF) through the provision of the unique facilities located at the Salisbury Research Facility is acknowledged as critical to facilitate studies of this nature.

\section{REFERENCES CITED}

Arenas, J. M., Narbón, J. J., and Alia, C. (2010). "Optimum adhesive thickness in structural adhesives joints using statistical techniques based on Weibull distribution," International Journal of Adhesion and Adhesives 30(3), 160-165. DOI: 10.1016/j.ijadhadh.2009.12.003 
AS/NZS 1328.1:1998 (2011). "Glued laminated structural timber. Part 1: Performance requirements and minimum production requirements," Standards Australia, Sydney, Australia.

AS/NZS 1720.2 (2006). “Timber structure, Part 2: Timber properties,” Standards Australia, Sydney, Australia.

AS/NZS 1748.1 (2011). "Timber - Solid - Stress-graded for structural purposes General requirements," Standards Australia, Sydney, Australia.

Bastani, A., Adamopoulos, S., Koddenberg, T., and Militz, H. (2016). "Study of adhesive bondlines in modified wood with fluorescence microscopy and X-ray microcomputed tomography," International Journal of Adhesion and Adhesives 68, 351358. DOI: 10.1016/j.ijadhadh.2016.04.006.

Bomba, J., Šedivka, P., Hýsek, S., Fáber, J., and Oberhofnerová, E. (2018). "Influence of glue line thickness on the strength of joints bonded with PVAc adhesives," Forest Products Journal 68(2), 120-126. DOI: 10.13073/FPJ-D-17-00038

Brady, D. E., and Kamke, F. A. (1988). "Effects of hot-pressing parameters on resin penetration," Forest Products Journal 38(11/12), 63-68.

Collett, B. M. (1972). "A review of surface and interfacial adhesion in wood science and related fields," Wood Science and Technology 6, 1-42. DOI: 10.1007/BF00351806

Cool, J., and Hernández. R. E. (2011). "Evaluation of four surfacing methods on black spruce wood in relation to poly vinyl acetate gluing performance," Wood and Fiber Science 43(2), 194-205.

Crafford, P. L. (2013). An Investigation of Selected Mechanical and Physical Properties of Young, Unseasoned and Finger-jointed Eucalyptus grandis Timber, Master's Thesis, University of Stellenbosch, Stellenbosch, South Africa.

da Silva, L. F. M., Rodrigues, T. N. S. S., Figueiredo, M. A. V., de Moura, M. F. S. F, and Chousal. J. A. G. (2006). "Effect of adhesive type and thickness on the lap shear strength," The Journal of Adhesion 82(11), 1091-1115. DOI:

10.1080/00218460600948511

Dadswell, H. E. (1972). The Anatomy of Eucalypt Woods (Paper No, 66), Forest Products Laboratory, Division of Applied Chemistry Technological, Commonwealth Scientific and Industrial Research Organisation (CSIRO), Canberra, Australia.

Dugmore, M. K. (2018). Evaluation of the Bonding Quality of E. grandis Crosslaminated Timber Made With a One-component Polyurethane Adhesive, Master's Thesis, Stellenbosch University, Stellenbosch, South Africa.

Duhamel, G. (2016). "Why you have voids in your cured adhesive," (https://www.applitec.com/articles/voids-cured-adhesive/), Accessed 11 January 2021.

Evans, P. D., Morrison, O., Senden, T. J., Vollmer, S., Roberts, R. J., Limaye, A., Arns, C. H., Averdunk, H., Lowe, A., and Knackstedt, M. A. (2010). "Visualisation and numerical analysis of adhesive distribution in particleboard using X-ray microcomputed tomography," International Journal of Adhesives and Adhesion 30(8), 754762. DOI: 10.1016/j.ijadhadh.2010.08.001

Frihart, C. R. (2004). "Adhesive interactions with wood," in: Fundamentals of Composite Processing: Proceedings of a Workshop, J. E. Winandy and F. A. Kamke (eds.), General technical report FPL-GTR-149, US Department of Agriculture, Forest Service, Forest Products Laboratory, Madison, WI.

Frihart, C. R. (2012). "Adhesive groups and how they relate to the durability of bonded wood," Journal of Adhesion Science and Technology 23(4), 601-617. DOI: 10.1163/156856108X379137 
Frihart, C. R. (2013). "Wood adhesion and adhesives," in: Handbook of Wood Chemistry and Wood Composites, $2^{\text {nd }}$ Edition, R. M. Rowell (ed.), CRC Press, Boca Raton, FL.

Hass, P., Wittel, F. K., Mendoza M., Herrmann, H. J., and Niemz, P. (2012). "Adhesive penetration in beech wood: Experiments," Wood Science and Technology 46, 243256. DOI: $10.1007 / \mathrm{s} 00226-011-0410-6$

Herczeg, A. (1965). "Wettability of wood," Forest Products Journal 15(11), 499-505.

Hse, C. Y. (1968). "Gluability of southern pine earlywood and latewood," Forest Products Journal 18(12), 32-36.

Jakes, J. E., Frihart, C. R., Hunt, C. G., Yelle, D. J., Plaza, N. Z., Lorenz, L. F., and Ching, D. J. (2018). "Integrating multiscale studies of adhesive penetration into wood," Forest Products Journal 68(4), 340-348. DOI: 10.13073/FPJ-D-17-00067

Kamke, F. A. and Lee, J. N. (2007). "Adhesive penetration in wood - A review," Wood and Fiber Science 39(2), 205-220.

Kamke, F. A., Nairn, J. A., Muszynski, L., Paris, J. L., Schwarzkopf, M., and Xiao, X. (2014). "Methodology for micro-mechanical analysis of wood-adhesive bonds using X-ray computed tomography and numerical modelling," Wood and Fiber Science 46(1), 15-28.

Kellar, E. J. C. (2005). "Joining similar and dissimilar materials," in: Adhesive Bonding Science, Technology and Applications, R. D. Adams (ed.) CRC Press, Boca Raton, FL.

Kläusler, O., Rehm, K., Elstermann, F., and Niemz, P. (2014). "Influence of wood machining on tensile shear strength and wood failure percentage of one-component polyurethane bonded wooden joints after wetting," International Wood Products Journal 5(1), 18-26. DOI: 10.1179/204264531Y.0000000039

Knorz, M., Neuhaeuser, E., Torno, S., and van de Kuilen, J.-W. (2015). "Influence of surface preparation methods on moisture-related performance of structural hardwoodadhesive bonds," International Journal of Adhesion and Adhesives 57, 40-48. DOI: 10.1016/j.ijadhadh.2014.10.003

Kurt, R., and Cil, M. (2012). "Effects of press pressures on glue line thickness and properties of laminated veneer lumber glued with phenol formaldehyde adhesive," BioResources 7(4), 5346-5354. DOI: 10.15376/biores.7.4.5346-5354

Leggate, W., McGavin, R. L., Miao, C., Outhwaite, A, Chandra, K. A., Dorries, J., Kumar, C., and Knackstedt, M. (2020). "The influence of mechanical surface preparation methods on southern pine and spotted gum wood properties: Wettability and permeability," BioResources 15(4), 8554-8576. DOI: 10.15376/biores.15.4.85548576

Leggate, W., McGavin, R. L., Outhwaite, A., Kumar, C., Faircloth, A., and Knackstedt, M. (2021a). "The influence of mechanical surface preparation methods on the bonding of southern pine and spotted gum: Tensile shear strength of lap joints," BioResources 16(1), 46-61. DOI: 10.15376/biores.16.1.46-61

Leggate, W., McGavin, R. L., Outhwaite, A., Dorries, J., Robinson, R., Kumar, C., Faircloth, A., and Knackstedt, M. (2021b). "The influence of mechanical surface preparation method, adhesive type and curing temperature on the bonding of Darwin stringybark," BioResources 16(1), 302-323. DOI: 10.15376/biores.16.1.302-323

Leggate, W., Kumar, C., McGavin, R. L., Faircloth, A., and Knackstedt, M. (2021c). "The effects of drying method on the wood permeability, wettability, treatability, and gluability of southern pine from Australia," BioResources 16(1), 698-720. DOI: 10.15376/biores.16.1.698-720 
Luedtke, J., Amen, C., van Ofen, A., and Lehringer, C. (2015). “1C-PUR-bonded hardwoods for engineered wood products: Influence of selected processing parameters," European Journal of Wood Products 73, 167-178. DOI: 10.1007/s00107-014-0875-8

Marra, A. A. (1992). Technology of Wood Bonding: Principles in Practice (VNR Structural Engineering), $1^{\text {st }}$ Edition, Van Nostrand Reinhold, New York, NY.

McKinley, P. E., Ching, D. J., Kamke, F.A., Zauner, M., and Xiao, X. (2016). "Micro Xray computed tomography of adhesive bonds in wood," Wood and Fiber Science 48(SI), 2-16.

Modzel, G., Kamke, F. A., and de Carlo, F. (2011). "Comparative analysis of a wood: Adhesive bondline," Wood Science and Technology 45(1), 147-158. DOI: 10.1007/S00226-010-0304-z

Paris, J. L. (2014). Wood Adhesive Bondline Analyses With Micro X-ray Computed Tomography. Ph.D. Dissertation, Oregon State University, Oregon.

Paris, J. L., Kamke, F. A., and Xiao, X. (2015). "X-ray computed tomography of woodadhesive bondlines: Attenuation and phase-contrast effects," Wood Science and Technology 49, 1185-1208. DOI: 10.1007/s00226-015-0750-8

Paris, J. L. and Kamke, F. A. (2015). "Quantitative wood-adhesive penetration with Xray computed tomography," International Journal of Adhesion and Adhesives 61,7180. DOI: 10.1016/j.ijadhadh.2015.05.006

Permabond (2021a). "How to eliminate air from adhesive and remove air from a bond joint," (https://www.permabond.com/resource-center/eliminate-air-adhesive-removeair-bond-joint/), Accessed $10^{\text {th }}$ January 2021.

Permabond (2021b). "Help! I've got air in the bond line," (https://www.permabond.com/resource-center/help-ive-got-air-in-the-bond-line/), Accessed $10^{\text {th }}$ January 2021.

Pröller, M., Nocetti, M., Brunetti, M., Barbu, M.-C., Blumentritt, M., and Wessels, C. B. (2018). "Influence of processing parameters and wood properties on the edge gluing of green Eucalyptus grandis with a one-component PUR adhesive," European Journal of Wood and Wood Products 76, 1195-1204. DOI: 10.1007/s00107-08181313-0

Qin, L., Lin, L., Fu, F., and Fan, M. (2017). "Microstructure and quantitative micromechanical analysis of wood cell-emulsion polymer isocyanate and ureaformaldehyde interphases," Microscopy and Microanalysis 23(3), 687-695. DOI: $10.1017 /$ S1431927617000216

Queensland Government (2021). "Wood properties and uses of Australian timbers: Spotted gum," (https://www.business.qld.gov.au/industries/farms-fishingforestry/forests-wood/properties-timbers/spotted-gum), Accessed 12 ${ }^{\text {th }}$ January 2021.

Redman, A. L., Bailleres, H., Turner, I., and Perré, P. (2016). "Characterisation of wood water relationships and transverse anatomy and their relationship to drying degrade," Wood Science and Technology 50, 739-757. DOI:10.1007/s00226-016-0818-0

Sage, G. N., and Tiu, W. P. (1982). "The effect of glue-line voids and inclusions on the fatigue strength of bonded joints in composites," Composites 13(3), 228-232. DOI: 10.1016/0010-4361(82)90004-0

Scheikl, M., and Dunky, M. (1998). "Measurement of dynamic and static contact angles on wood for the determination of its surface tension and the penetration of liquids into the wood surface," Holzforschung 52, 89-94. DOI: 10.1515/hfsg.1998.52.1.89. 
Schneider, C. A., Rasband, W. S., and Eliceiri, K. W. (2012). "NIH Image to ImageJ: 25 years of image analysis," Nature Methods 9(7), 671-675. DOI: 10.1038/nmeth.2089

Sernek, M., Resnik, J., and Kamke, F. A. (1999). "Penetration of liquid ureaformaldehyde adhesive into beech wood," Wood and Fiber Science 31(1), 41-48.

Vella, R., Heitzmann, M. T., Redman, A., and Bailleres, H. (2019). "Comparison of test methods for the determination of delamination in glued laminated timber," BioResources 14(4), 7920-7934. DOI: 10.15376/biores.14.4.7920-7934

Vella, R. (2020). Improving the Adhesion of High-density Softwoods with Isocyanate Based Adhesives, Master's Thesis, University of Queensland, Brisbane, Australia.

Wetzig, M. (2009). Studies on the Optimization of Bonding Hardwoods [Untersuchungen zur Optimierung der Verklebung von Laubholz], Diplom Thesis, ETH Zurich, Institute for Building Materials and Wood Physics. University of Cooperative Education Sachsen, Dresden, Germany.

Wetzig, M., Haß, P., Niemz, P., and Hänsel, A. (2011). "Investigation on bonding of three-layer cross laminated timber using hardwood [Untersuchungen zur Verklebung dreischichtiger Massivholzplatten unter Verwendung von Laubholz]," Bautechnik 88(10), 687-693. DOI: 10.1002/bate.201101490

White, M. S. (1977). "Influence of resin penetration on the fracture toughness of wood adhesive bonds," Wood Science 10(1), 6-14.

Article submitted: April 4, 2021; Peer review completed: May 16, 2021; Revisions accepted: May 22, 2021; Published: May 27, 2021.

DOI: $10.15376 /$ biores.16.3.5058-5082 